\title{
Estradiol selectively stimulates endothelial prostacyclin production through estrogen receptor- $\alpha$
}

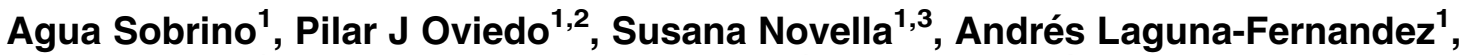 \\ Carlos Bueno ${ }^{1,3}$, Miguel Angel García-Pérez ${ }^{1}$, Juan $\mathrm{J}_{\text {Tarín }}{ }^{4}$, Antonio Cano ${ }^{5}$ \\ and Carlos Hermenegildo ${ }^{3}$ \\ ${ }^{1}$ Research Foundation, and ${ }^{2}$ Cardiology Service, Hospital Clínico Universitario, Avenida Blasco Ibañez, 17, E 46010 Valencia, Spain
${ }^{3}$ Departments of Physiology, ${ }^{4}$ Functional Biology and Physical Anthropology and ${ }^{5}$ Pediatrics, Obstetrics and Gynaecology, University of Valencia,
Avenida Blasco Ibañez, 15, E 46010 Valencia, Spain \\ (Correspondence should be addressed to C Hermenegildo; Email: carlos.hermenegildo@uv.es)
}

\begin{abstract}
Estradiol $\left(E_{2}\right)$ acts on the endothelium to promote vasodilatation through the release of several compounds, including prostanoids, which are products of arachidonic acid metabolism. Among these, prostacyclin (PGI2) and thromboxane A2 (TXA2) exert opposite effects on vascular tone. The role of different estrogen receptors (ERs) in the PGI2/TXA2 balance, however, has not been fully elucidated. Our study sought to uncover whether $E_{2}$ enhances basal production of PGI2 or TXA2 in cultured human umbilical vein endothelial cells (HUVECs), to analyze the enzymatic mechanisms involved, and to evaluate the different roles of both types of ERs (ER $\alpha$ and $E R \beta)$. HUVECs were exposed to $E_{2}$, selective ER $\alpha(1,3,5-$ tris(4-hydroxyphenyl)-4-propyl-1h-pyrazole, PPT) or ER $\beta$ (diarylpropionitrile, DPN) agonists and antagonists (unspecific: ICI 182 780; specific for ER $\alpha$ : methyl-piperidino-pyrazole, MPP). PGI2 and TXA2 production was measured by ELISA. Expression of phospholipases, cyclooxygenases (COX-1 and COX-2), PGI2 synthase (PGIS), and thromboxane synthase (TXAS) was analyzed by western blot and quantitative RT-PCR. $E_{2}(1-100 \mathrm{nM})$ dose dependently increased PGI2 production (up to 50\%), without affecting TXA2 production. COX-1 and PGIS protein and gene expressions were increased, whereas COX-2, phospholipases, and TXAS expression remained unaltered. All these effects were mediated through $\mathrm{ER} \alpha$, since they were produced not only in the presence of $\mathrm{E}_{2}$, but also in that of PPT, while they were abolished in the presence of MPP. In conclusion, $E_{2}$, acting through $E R \alpha$, up-regulates COX-1 and PGIS expression, thus directing prostanoid balance toward increased PGI2 production.
\end{abstract}

Journal of Molecular Endocrinology (2010) 44, 237-246

\section{Introduction}

Epidemiological studies indicate that the incidence of cardiovascular disease is greater in men than in women throughout the world (Mendelsohn \& Karas 2005). In addition, since these differences dissipate after menopause, estrogens have been considered as vasoprotective hormones. The protective effect detected in a considerable number of observational clinical studies (Barrett-Connor \& Grady 1998) has not been confirmed by more recent randomized placebocontrolled trials designed to study the effects of hormonal therapy (Hulley et al. 1998, Grady et al. 2002). Nevertheless, a number of studies have demonstrated a favorable profile for estrogens in both experimental animal and in vitro models (Turgeon et al. 2006).

There is a body of evidence suggesting that estrogens exert cardiovascular effects via the promotion of endothelial vasodilator synthesis (Mendelsohn \& Karas 2005). Recent studies, however, have described clinical complications, such as thrombosis in veins and coronary arteries, developed in postmenopausal women during the administration of exogenous hormones (Cano et al. 2007).

Estradiol $\left(\mathrm{E}_{2}\right)$ is the most potent estrogen in humans, and exerts its actions mainly through binding and the activation of estrogen receptors (ERs). Two major subtypes of ERs (ER $\alpha$ and ER $\beta$ ) have been identified, although the contribution of both receptors to the regulation of vascular effects is still obscure (Cano \& Hermenegildo 2000). There is controversy over whether estrogenic effects are mediated through ER $\alpha$, $\mathrm{ER} \beta$, or both. Recently, selective $\mathrm{ER} \alpha$ agonist (1,3,5-tris (4-hydroxyphenyl)-4-propyl-1h-pyrazole, PPT), selective $\mathrm{ER} \beta$ agonist (diarylpropionitrile, DPN), and selective $\mathrm{ER} \alpha$ antagonist (methyl-piperidino-pyrazole, MPP) have become available (Krom et al. 2007).

The prostanoids prostacyclin (PGI2) and thromboxane A2 (TXA2) play an essential role in the maintenance of vascular homeostasis. PGI2 is a vasodilator and an inhibitor of platelet aggregation; in contrast, TXA2 is a vasoconstrictor and a promoter of platelet aggregation. As a consequence of their opposing roles, an imbalance in PGI2 or TXA2 production has 
been implicated in the pathophysiology of many thrombotic and cardiovascular disorders (Bunting et al. 1983). Both metabolites are products of arachidonic acid metabolism, preceded by phospholipases (cPLAs; PLA2G4A and PLA2G4B), and are metabolized by cyclooxygenases (COX-1 and COX-2). The COX product is metabolized by the terminal synthase enzymes, PGI2 synthase (PGIS) or thromboxane synthase (TXAS), to become PGI2 or TXA2 respectively (Hermenegildo et al. 2006). Because the balance between PGI2 and TXA2 production is central in the maintenance of vascular tone and platelet aggregation, it is important to determine the role of these enzymes in the regulation of prostanoid biosynthesis by the endothelium.

Although there is evidence that PGI2 release from endothelial cells is increased by $\mathrm{E}_{2}$ (Mikkola et al. 1995), less is known about the effect of $\mathrm{E}_{2}$ on the enzymes involved in the prostanoid pathway in cultured human umbilical vein endothelial cells (HUVECs), and the role of both ERs. Therefore, our aims were to study the synthesis of PGI2 and TXA2 metabolites when HUVECs are exposed to $\mathrm{E}_{2}$, and the enzymes involved in the production of both prostanoids. Moreover, we sought to uncover the role of ER $\alpha$ and ER $\beta$ in the observed effects.

\section{Materials and methods}

\section{Cell culture and experimental design}

Primary HUVECs were isolated by collagenase treatment of human umbilical veins from 12 healthy donors as described previously (Monsalve et al. 2007). Briefly, HUVECs were grown in $75-\mathrm{cm}^{2}$ flasks (Orange Scientific, Waterloo, Belgium) in human endothelial cell-specific medium EBM-2 (Lonza, Verviers, Belgium) supplemented with EGM-2 (Lonza) in an incubator at $37^{\circ} \mathrm{C}$ with $5 \% \mathrm{CO}_{2}$.

Cells were identified as endothelial by their characteristic cobblestone morphology and by the presence of von Willebrand factor by immunocytochemistry using a specific antibody (F-3520; Sigma). At the second passage, $100 \%$ of the cells in the cultures were positive for von Willebrand factor. Cells from passages 4 to 6 were seeded into 6-well plates with fibronectin-treated coverslides for immunocytochemistry, into 24-well plates for PGI2 and TXA2 measurements, into 96-well plates for the measurement of cell viability, and into 25- $\mathrm{cm}^{2}$ flasks for western blot and mRNA isolation. When cells reached $75 \%$ of confluence, culture medium was exchanged for a phenol red-free Medium 199 (Gibco, Invitrogen) supplemented with steroiddeprived (by charcoal/dextran treatment) $20 \%$ fetal bovine serum (Gibco), and maintained for $24 \mathrm{~h}$. Then, the culture medium was eliminated and immediately replaced with phenol red-free Medium 199.
The desired concentrations of $\mathrm{E}_{2}$ (Sigma) were obtained by successive dilutions of a stock solution with ethanol. The desired concentrations of the selective ER $\alpha$ agonist (PPT), the selective ER $\beta$ agonist (DPN), the selective ER $\alpha$ antagonist (MPP), or the ER antagonist (ICI 182 780), all of them from Tocris Bioscience (Ellisville, MI, USA), were obtained by successive dilutions of a stock solution with DMSO. Control cells were exposed to the same vehicles $(<0 \cdot 1 \%$ ethanol or $0 \cdot 1 \%$ DMSO respectively). Each experiment was performed in a different cell culture.

This investigation conforms to the principles outlined in the Declaration of Helsinki, and was approved by the institutional review board at our center, and written informed consent was obtained from all donors.

\section{Assay of PGI2 and TXA2}

After treatment with the desired products, the medium was collected and stored at $-20^{\circ} \mathrm{C}$ until TXA2 or PGI2 was measured. Culture wells were then washed with PBS, and adherent cells were collected in $0.5 \mathrm{M} \mathrm{NaOH}$ for protein determination by the modified Lowry's method using BSA as a standard (Lowry et al. 1951).

The amount of PGI2 produced, calculated as the concentration of stable hydrolysis product, 6-ketoprostaglandin-F1 $\alpha$, was assessed in duplicate using a commercial EIA kit (Cayman Chemical, Ann Arbor, MI, USA). The production of PGI2 was expressed as ng $\mathrm{PGI} / \mathrm{mg}$ protein.

TXA2 is rapidly hydrolyzed non-enzymatically to form the stable metabolite thromboxane B2, which was assessed in duplicate using a commercial EIA kit (Cayman Chemical), and the results were expressed as pg thromboxane/mg protein.

\section{Immunoblotting}

HUVECs were treated in $25-\mathrm{cm}^{2}$ flasks for $24 \mathrm{~h}$ with the desired products. A volume of $150 \mu \mathrm{l}$ of lysis buffer $(0 \cdot 1 \%$ triton X-100, $0 \cdot 5 \%$ sodium deoxycholate acid, $0 \cdot 1 \%$ SDS, $0 \cdot 1 \%$ phenylmethanesulfonylfluoride, or phenylmethylsulfonyl fluoride in $100 \mathrm{ml}$ of PBS containing protease inhibitors: $1 \mu \mathrm{g} / \mathrm{ml}$ leupeptin, $0.5 \mu \mathrm{g} / \mathrm{ml}$ pepstatin, and $1 \mu \mathrm{g} / \mathrm{ml}$ bestatin) was added and maintained at $4{ }^{\circ} \mathrm{C}$ for $30 \mathrm{~min}$. Then, the cells were collected using a cell scraper, boiled for $5 \mathrm{~min}$, and sonicated for $10 \mathrm{~s}$. Protein content was measured (Lowry et al. 1951), and the samples were frozen at $-20{ }^{\circ} \mathrm{C}$ until assay.

Equal amounts of protein $(60-150 \mu \mathrm{g})$ were then separated by $10 \%$ of SDS-PAGE, and the protein was transferred to PVDF sheets (Bio-Rad). Immunostaining was achieved using specific antibodies antiER $\alpha$ (sc-8002; Santa Cruz Biotechnology, Santa Cruz, CA, USA), anti-ER $\beta$ (sc-8974; Santa Cruz 
Biotechnology), anti-COX-1 (cat 236003; Calbiochem, Darmstadt, Germany), anti-COX-2 (cat 160107; Cayman Chemical), and anti-prostaglandin I synthase (cat 100023; Cayman Chemical). Development was performed with alkaline-phosphatase-linked appropriate secondary antibodies (from Sigma), followed with nitroblue tetrazolium/5-bromo-4-chloro-3-indolyl phosphate, $p$-toluidine salt color development reaction. Blots were digitalized using a Gelprinter PLUS (TDI, Madrid, Spain), and the densities of spots were analyzed with the program Image Gauge 4.0 (Science Lab. 2007, Fuji Photo Film, Tokyo, Japan). Equivalent protein loading and transfer efficiency were verified by staining for $\beta$-actin (Sigma).

\section{RNA isolation and quantitative real-time PCR (qRT-PCR) assay}

Total RNA was extracted by using TRIzol reagent (Invitrogen) following the manufacturer's instructions. Reverse transcription (RT) was carried out using SuperScript First-Strand Synthesis System for RT-PCR (Invitrogen) by using a personal Mastercycler Eppendorf Thermocycler (Eppendorf, Hamburg, Germany). One microgram of total RNA was reverse transcribed to cDNA following the manufacturer's instructions. For each RT, a blank was prepared using all the reagents except the RNA sample (for which an equivalent volume of diethyl pyrocarbonate (DEPG)-treated water was substituted), and was used as a non-template control in qRT-PCR experiments.

The qRT-PCR data for PGIS, TXAS, PLA2G4A, PLA2G4B and GAPDH (endogenous control) were obtained with TaqMan assays (Hs00168766_m1, Hs00233423_m, Hs00233352_m1, Hs00192661_m1, and $4326317 \mathrm{E}$ respectively) performed with TaqMan Universal Mastermix (Applied Biosystems, Foster City, CA, USA). Reaction mix was prepared in RNase-free tubes of $0.2 \mathrm{ml}$ by adding a volume of TaqMan Universal PCR Master Mix and TaqMan Gene Expression Assay. The sample of cDNA obtained from the RT was incorporated with the necessary quantity of DEPC-treated water to get a final concentration of $40 \mathrm{ng}$ approximately (range: 10-100 ng). The appropriate volume of each reaction mixture was transferred to a reaction plate, which was then placed in a 7900HT Fast Real-Time PCR System (Applied Biosystems) with the appropriate thermal cycling conditions $\left(50{ }^{\circ} \mathrm{C} / 2 \mathrm{~min}, 95^{\circ} \mathrm{C} / 10 \mathrm{~min}, 40\right.$ cycles; $95^{\circ} \mathrm{C} / 15 \mathrm{~s}$, $\left.60^{\circ} \mathrm{C} / 1 \mathrm{~min}\right)$. Each sample was amplified in triplicate for each gene. Data were analyzed with the SDS 2.2.2 software (Applied Biosystems).

In the case of COX-1 and COX-2, qRT-PCR assays were performed using an ABI PRISM 7700 Sequence Detection System (Applied Biosystems) with a heated lid $\left(105^{\circ} \mathrm{C}\right)$, an initial denaturation step at $95^{\circ} \mathrm{C}$ for
$10 \mathrm{~min}$, followed by 40 cycles of $95^{\circ} \mathrm{C}$ for $15 \mathrm{~s}$ and $60^{\circ} \mathrm{C}$ for $1 \mathrm{~min}$. To amplify cDNA, the RT samples were diluted $1 / 10$. In each reaction, a total of $1 \mu \mathrm{l}$ from each RT tube was mixed with $12.5 \mu \mathrm{l}$ of SYBR Green PCR master mix (Applied Biosystems) containing nucleotides, Taq DNA polymerase, $\mathrm{MgCl}_{2}$, and reaction buffer with SYBR green; $1.5 \mu \mathrm{l}$ of $5 \mu \mathrm{M}$ adequate primers and DEPCtreated water were added to a final volume of $25 \mu \mathrm{l}$. In parallel, fivefold serial dilutions of well-known DNA concentrations were run as calibration curves. After the amplification process was ended, the melting curves program was used to assure that all the amplicons were obtained at the same temperature, and to assure there was no amplification of other products. Primers were designed using the Primers Express Software (Applied Biosystems), and were synthesized by Custom Primers (Life Technologies). The sequence of the GAPDH sense primer was $5^{\prime}$-CTGCTCCTCCTGTTCGACAGT-3' and that of the antisense primer was 5'-CCGTTGACTCCGACCTTCAC-3' (NCBI\#: NM_002046), giving rise to an expected PCR product of $100 \mathrm{bp}$. The COX-1 primers, $5^{\prime}$-TACTCACAGTGCGCTCCAAC-3' for the sense primer and 5'-GCAACTGCTTCTTCCCTTTG-3' for the antisense (NCBI\#: AF440204), were designed to amplify a 168 bp PCR product. For COX-2, the primers used were $5^{\prime}$-ATCATAAGCGAGGGCCAGCT-3' for the sense primer and $5^{\prime}$-AAGGCGCAGTTTACGCTGTC-3' for the antisense one, and a $101 \mathrm{bp}$ product was expected (NCBI\#: D28235). Data were analyzed with the ABI PRISM Sequence Detection v. 1.7 analysis software (Perkin Elmer, Nieuwerkerk, The Netherlands). Duplicates showing more than a $5 \%$ variation were discarded. To validate a qRT-PCR, standard curves with $r>0.95$ and slope values between $-3 \cdot 1$ and $-3 \cdot 4$ were required.

The amounts of COX-1 and COX-2 were relatively quantified based on the work of Pfaffl MW (Pfaffl et al. 2002). In some samples, PCR bands were purified using a MiniElute PCR Purification Kit (Qiagen), and were then sequenced to prove that the amplified products corresponded to previously published COX-1, COX-2, and GAPDH sequences. Agarose gel electrophoreses were also performed to demonstrate that qRT-PCR yielded a unique band.

\section{Cell viability measurement}

The possible toxic effect of the compounds that were used on HUVECs was discarded by the measurement of cell respiration, an indicator of cell viability, which was assessed by mitochondria-dependent reduction of 3-(4,5-dimethylthiazol-2-yl)-2,5-diphenyltetrazolium bromide to formazan (Oviedo et al. 2004).

Cell viability after all treatments ( $\mathrm{E}_{2}$, ICI 182780 , PPT, DPN, MPP, and their combinations) was the same as that of the control cells that were maintained without treatments (data not shown). 


\section{Statistical analysis}

Values shown in the text and figures are mean \pm s.E.M. ANOVA was applied for comparisons of means, and then Bonferroni's test was performed. $P$ values $<0.05$ were considered significant. The statistical analysis was carried out using the Prism 4 software (GraphPad Software Inc., San Diego, CA, USA).

\section{Results}

\section{HUVECs express both subtypes of ERs}

The first step of the present work was to ensure the presence of ERs on HUVECs. Western blot analysis confirmed the presence of ER $\alpha$ and ER $\beta$ (Fig. 1). Moreover, not only the full-length $66 \mathrm{kDa} \mathrm{ER} \alpha$ but also the short $46 \mathrm{kDa} \mathrm{ER} \alpha$ is expressed in cultured endothelial cells, although the $66 \mathrm{kDa} \mathrm{ER} \alpha$ is the main form. There were no differences in ER protein expression between different cell cultures. In addition, no changes in protein expression of both types of ERs were observed after exposure to $\mathrm{E}_{2}$, ICI 182780 , or $\mathrm{E}_{2}$ plus ICI 182780 (Fig. 1).
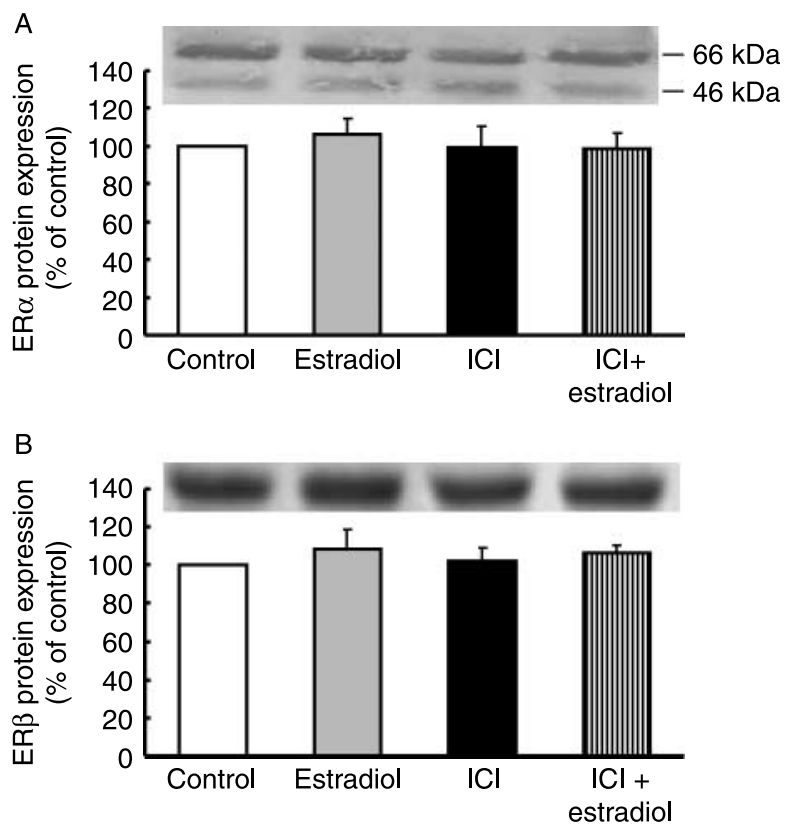

Figure 1 Estrogen receptor- $\alpha$ and estrogen receptor- $\beta$ protein expression in HUVECs. Cells were exposed to $1 \mathrm{nM}$ estradiol with or without $1 \mu \mathrm{M} \mathrm{ICl} 182780$ for $24 \mathrm{~h}$, and protein expression of $(A) E R \alpha$ and (B) ER $\beta$ was measured as stated in Materials and methods. A typical immunoblotting image and relative levels assessed by densitometry of bands of $66 \mathrm{kDa}(\mathrm{ER} \alpha)$ or $56 \mathrm{kDa}$ $(E R \beta)$ are presented. Data are expressed as the percentage of the control values, and are mean \pm S.E.M. of six values (three different experiments performed in cells from different cultures).

\section{Selective ER $\alpha$ activation increased PGI2 production}

To investigate the effects of $\mathrm{E}_{2}$ on PGI2 and TXA2 production, HUVECs were first exposed to 1 and $10 \mathrm{nM}$ of $\mathrm{E}_{2}$ during different incubation times up to $48 \mathrm{~h}$ (Fig. 2). Exposure to $1 \mathrm{nM} \mathrm{E_{2 }}$ increased PGI2 production, compared with the control values, after $24 \mathrm{~h}(P<0 \cdot 05)$, and the production remained augmented up to $48 \mathrm{~h}$, whereas $10 \mathrm{nM} \mathrm{E} \mathrm{E}_{2}$ increased PGI2 production after $8 \mathrm{~h} \quad(P<0.05$ versus control $)$. Differences between 1 and $10 \mathrm{nM} \mathrm{E_{2 }}$ effects were only significant at $24 \mathrm{~h}(P<0 \cdot 05)$. TXA2 remained unchanged after incubation with either 1 or $10 \mathrm{nM} \mathrm{E}_{2}$ at all the tested incubation times (data not shown). Therefore, the remaining experiments were performed at $24 \mathrm{~h}$ of incubation.

Exposure of endothelial cells to three different, physiological and near-physiological concentrations of $\mathrm{E}_{2}(1-100 \mathrm{nM})$ resulted in a dose-dependent increase of PGI2 production $\left(P<0.001 \mathrm{E}_{2} 10\right.$ or $100 \mathrm{nM}$ versus control, $P<0.05 \mathrm{E}_{2} 1 \mathrm{nM}$ versus control), increasing up to $50 \%$ when cells were exposed to $100 \mathrm{nM}$ (Fig. 3). Moreover, the effect of $100 \mathrm{nM}$ was significantly higher $(P<0.05)$ than that of $1 \mathrm{nM}$. These effects were mediated through ER activation, since the treatment of cells with the unspecific $\mathrm{E}_{2}$ receptor antagonist ICI $182780(1 \mu \mathrm{M})$ completely reverted the effect of $E_{2}$ at different concentrations (Fig. 3). To test whether the increased PGI2 production induced by $\mathrm{E}_{2}$ was mediated through ER $\alpha$ or ER $\beta$ activation, HUVECs were exposed to the selective ER agonists, PPT and DPN (Fig. 4). Treatment of cells with the ER $\alpha$ agonist PPT (1-100 nM) dose dependently increased PGI2 production. The effect afforded by $1 \mathrm{nM}$ PPT was

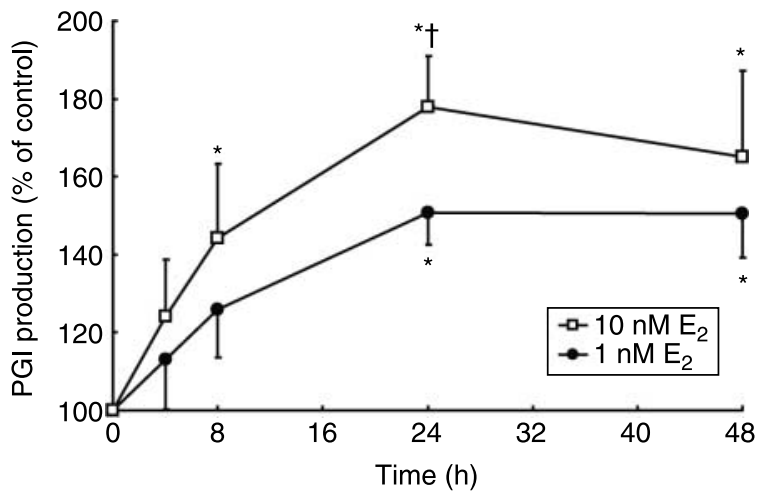

Figure 2 Time course of estradiol effects on PGI2 production by endothelial cells. Human umbilical vein endothelial cells were exposed to 1 or $10 \mathrm{nM}$ of $\mathrm{E}_{2}$ for the indicated time periods $(0-48 \mathrm{~h})$. Culture medium was then collected, and PGI2 concentration was measured as described in Materials and methods. Data are expressed as the percentage of the control values, and are mean \pm S.E.M. of five to six duplicated determinations corresponding to two different experiments performed in cells from different cultures. ${ }^{\star} P<0.05$ versus control values $($ time $=0)$ and ${ }^{\dagger} P<0.05$ vs $1 \mathrm{nM} \mathrm{E}_{2}$. 


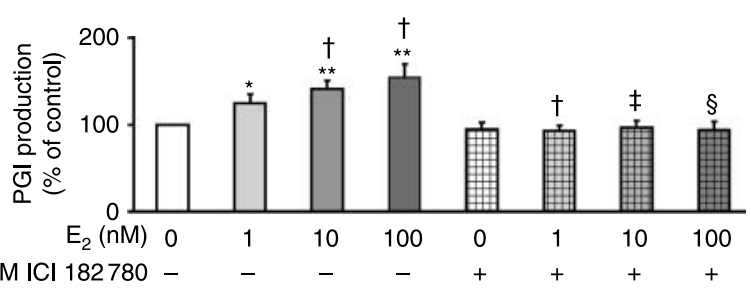

Figure 3 Dose-dependent increase of PGI2 production by endothelial cells after exposure to estradiol through ER activation. Steroid-deprived HUVECs were exposed to different concentrations (1-100 nM) of $E_{2}$ with or without ICI 182780 (ER-unspecific antagonist) for $24 \mathrm{~h}$. Culture medium was then collected, and PGI2 concentration was measured as described in Materials and methods. Data are expressed as the percentage of the control values, and are mean \pm S.E.M. of 10-17 duplicated determinations corresponding to four different experiments performed in cells from different cultures. Average control values for all experiments were $1.01 \pm 0.14 \mathrm{ng} / \mathrm{mg}$ protein (range: $0.45-1.78 \mathrm{ng} / \mathrm{mg}$ protein). ${ }^{\star} P<0.05$ versus control, ${ }^{\star *} P<0.001$ versus control, ${ }^{\dagger} P<0.05$ vs $1 \mathrm{nM} \mathrm{E}_{2},{ }^{\ddagger} P<0.05$ vs $10 \mathrm{nM} \mathrm{E}_{2}$, and ${ }^{\S} P<0.05$ vs $100 \mathrm{nM} \mathrm{E}_{2}$.

indistinguishable from control cells, whereas 10 and $100 \mathrm{nM}$ increased PGI2 production up to 133 and $154 \%$ of control values $(P<0.05$ versus control and versus $1 \mathrm{nM}$ PPT). Treatment with ER $\beta$ agonist DPN (1-100 nM), however, did not modify PGI2 production.

Therefore, it seems that $\mathrm{E}_{2}$ increased PGI2 acting through ER $\alpha$. To ensure the role of ER $\alpha$, cells were exposed to $\mathrm{E}_{2}$, PPT, and DPN, with or without the selective ER $\alpha$ antagonist MPP (Fig. 5). Treatment of cells with the ER $\alpha$ agonist PPT $(10 \mathrm{nM})$ increased PGI2 production to the same levels as those for $\mathrm{E}_{2}$ alone. Moreover, the ER $\alpha$ antagonist MPP $(1 \mu \mathrm{M})$ completely abolished both the $\mathrm{E}_{2}$ and the PPT effects $(P<0.05$ versus same treatment without MMP). Therefore, $\mathrm{E}_{2}$ effects on PGI production are mediated through ER $\alpha$ activation. This effect was selective for PGI2 production, since $\mathrm{E}_{2}$ or different $\mathrm{ER}$ agonists do not modify production of the related vasoconstrictor compound TXA2 (Fig. 6).

\section{$\mathrm{E}_{2}$ did not modify either PLA2G4A or PLA2G4B mRNA expression}

To examine the role of the first enzymes involved in prostanoid production, the gene expressions for both PLA2G4A and PLA2G4B enzymes were measured. Treatment of cells with $\mathrm{E}_{2}$ did not change their expressions (data not shown).

\section{Selective ER $\alpha$ activation increased COX-1 expression and production}

Experiments were performed in order to study the role of both enzymes COX-1 and COX-2. COX-1 mRNA expression was significantly increased by $15-20 \%$ in cells exposed to $\mathrm{E}_{2}$ or PPT respectively $\left(P<0.001 \mathrm{E}_{2}\right.$ versus control, $P<0 \cdot 05$ PPT versus control; Fig. 7A), without changes in the presence of the ER $\beta$ agonist DPN, suggesting that $\mathrm{E}_{2}$ increases COX-1 expression through ER $\alpha$ activation. Moreover, to confirm previous results on gene expression, the analysis of the protein content revealed that the COX-1 protein was significantly increased in cells exposed to either $\mathrm{E}_{2}$ or PPT $(P<0.05$ versus control; Fig. $7 \mathrm{~B}$ and $\mathrm{C})$ without changes in the presence of DPN. Exposure of endothelial cells to $\mathrm{E}_{2}$ did not modify either COX-2 expression or production (data not shown).

\section{$E_{2}$ increases PGIS but not TXAS expression}

To complete the analysis of the $\mathrm{E}_{2}$ effects on the enzymes implicated in prostanoid production, the last enzymes responsible for PGI2 and TXA2 prostanoid production were evaluated. PGIS mRNA levels increased by $170 \%$ (Fig. 8A), and protein PGIS production increased by $50 \%$ in cells treated with $\mathrm{E}_{2}$ or PPT (Fig. $8 \mathrm{~B}$ and $\mathrm{C}$ ). Moreover, in both cases, the effect was abolished in the presence of ER antagonist ICI $182780(1 \mu \mathrm{M})$ or selective ER $\alpha$ antagonist MPP $(1 \mu \mathrm{M})$. These results demonstrate an $\mathrm{E}_{2}$-increased expression and protein content of the PGIS enzyme through ER $\alpha$. In contrast, the treatment of cells with $\mathrm{E}_{2}$ did not modify TXAS mRNA expression (data not shown).

\section{Discussion}

In the present study, HUVECs were used to determine the role of $\mathrm{E}_{2}$ in the regulation of prostanoid synthesis. The molecular mechanisms of $\mathrm{E}_{2}$ action in prostanoid synthesis pathway were determined by measuring

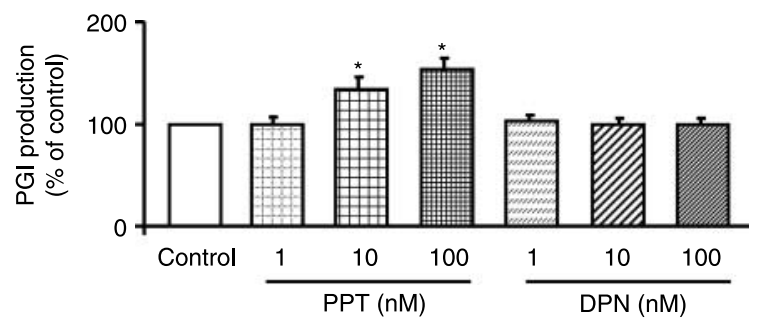

Figure 4 PPT, but not DPN, dose dependently increases PGI2 production by endothelial cells. Steroid-deprived HUVECs were exposed to different concentrations (1-100 nM) of PPT or DPN for $24 \mathrm{~h}$. Culture medium was then collected, and PGI2 concentration was measured as described in Materials and methods. Data are expressed as the percentage of the control values, and are mean \pm S.E.M. of 16-20 duplicated determinations corresponding to four different experiments performed in cells from different cultures. Average control values for all experiments were $1.04 \pm 0.08 \mathrm{ng} / \mathrm{mg}$ protein (range: $0.51-1.91 \mathrm{ng} / \mathrm{mg}$ protein). ${ }^{*} P<0.05$ versus control and versus $1 \mathrm{nM}$ PPT. 


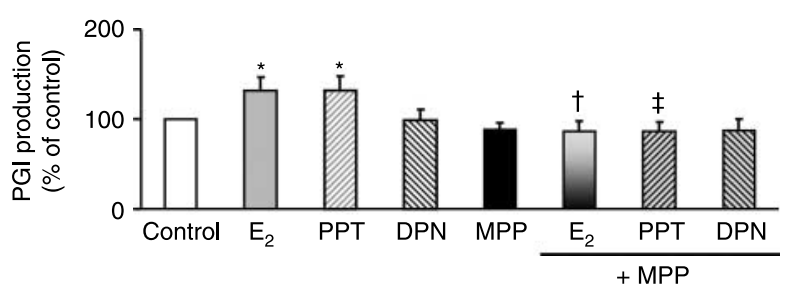

Figure 5 Estradiol-increased PGI2 production through $\mathrm{ER} \alpha$ activation. Steroid-deprived HUVECs were exposed to $10 \mathrm{nM}$ of $E_{2}$, PPT, or DPN, with or without $1 \mu \mathrm{M}$ MPP for $24 \mathrm{~h}$. Then, the culture medium was collected, and PGI2 concentration was measured as described in Materials and methods. Data are expressed as the percentage of the control values, and are mean \pm S.E.M. of 11-19 duplicated determinations corresponding to four different experiments performed in cells from different cultures. Average control values for all experiments were $1 \cdot 19 \pm 0.16 \mathrm{ng} / \mathrm{mg}$ protein (range: $0.31-1.97 \mathrm{ng} / \mathrm{mg}$ protein). ${ }^{\star} P<0.05$ versus control, ${ }^{\dagger} P<0.05$ vs $10 \mathrm{nM} \mathrm{E}_{2}$, and ${ }^{\ddagger} P<0.05$ vs 10 nM PPT.

the gene expression of PLAG4A2, PLAG4B2, COX-1, COX-2, PGIS, and TXAS; the protein production of COX-1, COX-2, and PGIS; and the production of PGI2 and TXA2.

Some authors have found that HUVECs do not express ER $\alpha$ (Toth et al. 2008), although other investigators have demonstrated the presence of both $E R \alpha$ and $E R \beta$ mRNAs in HUVECs (Wagner et al. 2001). Data presented in Fig. 1 demonstrate the expression of both ER $\alpha$ and ER $\beta$ proteins in HUVECs, thus confirming previous reports (Harris 2007, Oviedo et al. 2007). The full-length $66 \mathrm{kDa} \mathrm{ER} \alpha$ is the main form that is expressed in HUVECs, but the short $46 \mathrm{kDa}$ $\mathrm{ER} \alpha$ is also present, as it has been previously described (Haynes et al. 2003). The $46 \mathrm{kDa} \mathrm{ER} \alpha$ is sufficient to mediate several vascular effects of $\mathrm{E}_{2}$ in vivo, including both nuclear actions to increase NO production and reendothelialization process (Billon-Galés et al. 2009) and rapid, membrane-initiated effects such as the activation of endothelial nitric oxide synthase (Kim \& Bender 2009).

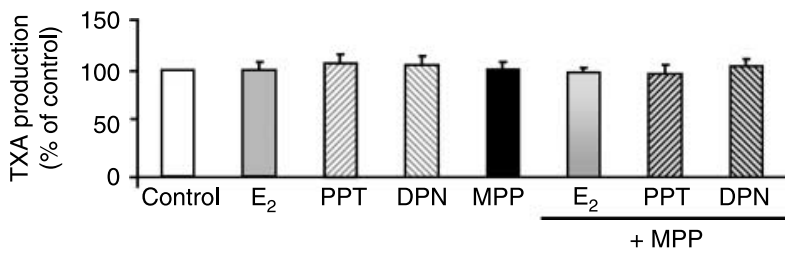

Figure 6 Estradiol did not modify TXA2 production. Steroiddeprived HUVECs were exposed to $10 \mathrm{nM}$ of $E_{2}$, PPT, or DPN, with or without $1 \mu \mathrm{M}$ MPP for $24 \mathrm{~h}$. Then, the culture medium was collected, and TXA2 concentration was measured as described in Materials and methods. Data are expressed as the percentage of the control values, and are mean \pm S.E.M. of 11-19 duplicated determinations corresponding to four different experiments performed in cells from different cultures. Average control values for all experiments were $992 \pm 100 \mathrm{pg} / \mathrm{mg}$ protein (range: 397-1617 pg/mg protein).
Time-course analysis, in which $\mathrm{E}_{2}$ effects on PGI2 are evident only after 8 or $24 \mathrm{~h}\left(10\right.$ and $1 \mathrm{nM} \mathrm{E_{2 }}$ respectively), suggests an ER-mediated genomic effect. Our study demonstrates that in HUVECs, activation of $\mathrm{ER} \alpha$ by $\mathrm{E}_{2}$ or PPT induces a dose-dependent up-regulation of PGI2 through increased COX-1 and PGIS gene and protein expression (Fig. 9). The vasoconstrictor metabolite TXA2, however, remained unaltered in the presence of $\mathrm{E}_{2}$. The observed effects, significant at 1 and $10 \mathrm{nM} \mathrm{E}_{2}$, are within physiological levels, with the same being achieved in plasma from women of fertile age (Hermenegildo et al. 2002). Consequently, the $10 \mathrm{nM} \mathrm{E}_{2}$ dose was chosen to carry out the experiments.

Our results are in agreement with several papers describing a relationship between estrogens and elevated PGI2. Thus, PGI2 appears to be involved in the atheroprotective effect of $\mathrm{E}_{2}$ (Arnal et al. 2004). Furthermore, PGI2 levels are elevated during
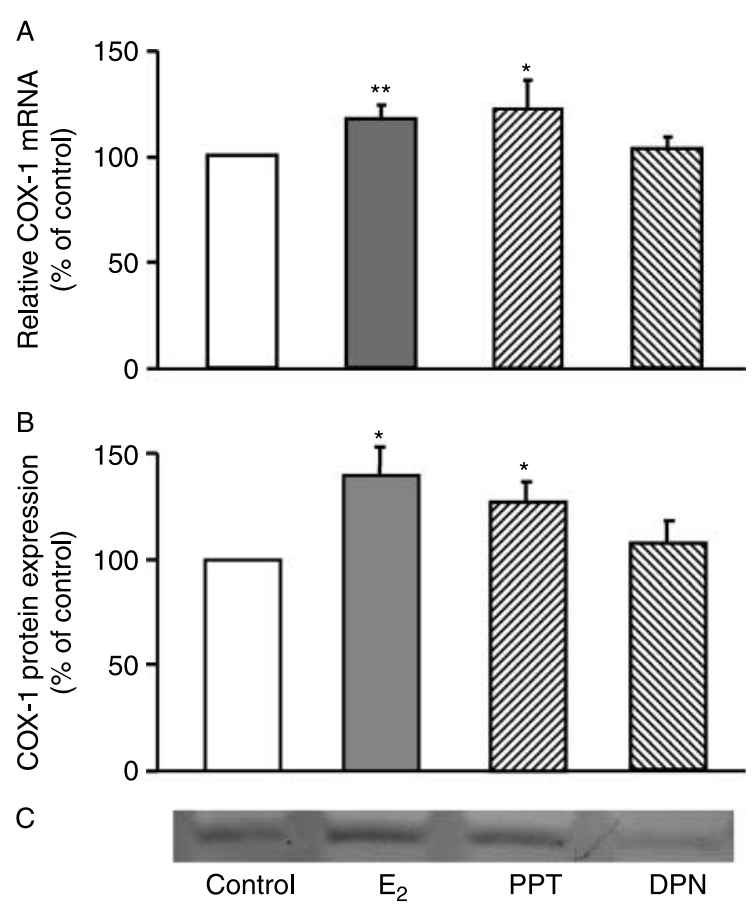

Figure 7 Estradiol-increased COX-1 mRNA and protein expression through ER $\alpha$ activation. Steroid-deprived HUVECs were exposed to $10 \mathrm{nM}$ of $\mathrm{E}_{2}$, PPT, or DPN for $24 \mathrm{~h}$. For mRNA expression (A), total RNA was extracted, and the relative expression of COX-1 was quantified by qRT-PCR as described in Materials and methods. For immunoblotting assay ( $B$ and $C$ ), cells were collected in a lysis buffer, and immunoblotted with specific anti-COX-1 antibody as described in Materials and methods. A typical immunoblotting image $(C)$ and relative levels assessed by densitometry of bands $(B)$ are presented. Data are expressed as the percentage of the control values, and are mean \pm S.E.M. of five to ten values corresponding to four experiments performed in cells from different cultures. ${ }^{*} P<0.05$ versus control and ${ }^{\star \star} P<0.001$ versus control. 


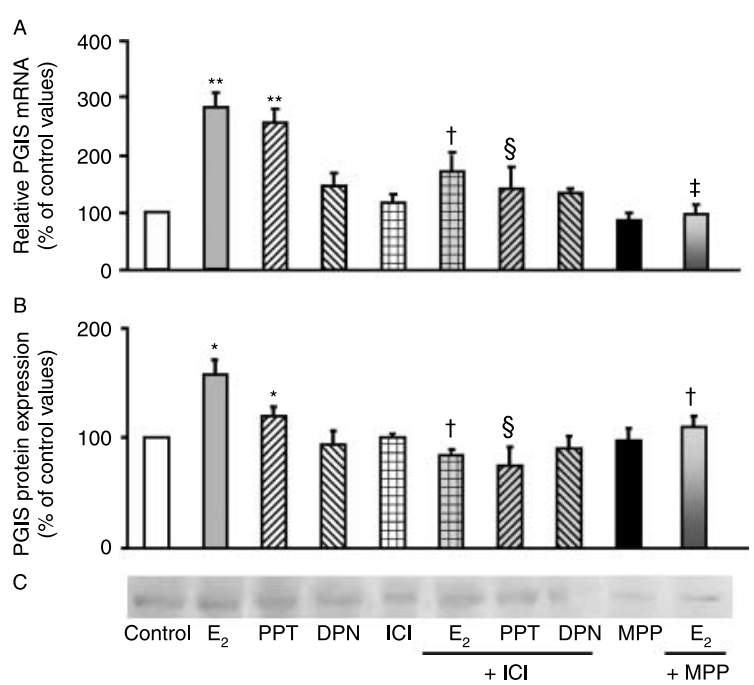

Figure 8 Estradiol-increased PGIS mRNA expression and protein production. Steroid-deprived HUVECs were exposed to $10 \mathrm{nM}$ of $\mathrm{E}_{2}$, PPT, or DPN, with or without $1 \mu \mathrm{M} \mathrm{ICl} 182780$ or $1 \mu \mathrm{M}$ MPP for $24 \mathrm{~h}$. For mRNA expression (A), total RNA was extracted, and the relative expression of PGIS was quantified by qRT-PCR as described in Materials and methods. For immunoblotting assays ( $B$ and $C)$, cells were collected in a lysis buffer and immunoblotted with specific anti-PGIS antibody as described in Materials and methods. A typical immunoblotting image $(C)$ and relative levels assessed by densitometry of bands (B) are presented. Data are expressed as the percentage of the control values, and are mean \pm S.E.M. of 6-16 values corresponding to four experiments performed in cells from different cultures. ${ }^{\star} P<0.05$ versus control, ${ }^{\star \star} P<0.001$ versus control, ${ }^{\dagger} P<0.05$ versus $\mathrm{E}_{2}$ alone, ${ }^{\ddagger} P<0.001$ versus $\mathrm{E}_{2}$ alone, and $\S P<0.05$ versus $\mathrm{PPT}$ alone.

pregnancy (Rupnow et al. 2002). In contrast, the decreased urine PGI2 metabolite observed after menopause is reversed in women receiving estrogen replacement therapy (Mueck et al. 2001).

Endothelium is the primary source of PGI2 production, and estrogens have been demonstrated to increase PGI2 levels. For example, $\mathrm{E}_{2}$ increases the release of PGI2 in a variety of artery preparations, including ovine uterine arteries, mesenteric arteries from ovariectomized rats, rat cerebral blood vessels, and aorta from ovariectomized monkeys (Hermenegildo et al. 2006). Regarding cultured endothelial cells, some discrepancies exist. $\mathrm{E}_{2}$ has been reported to increase PGI2 in HUVECs (Mikkola et al. 1995), and to show a neutral or even a decreasing effect in bovine coronary endothelial cells (Stewart et al. 1999).

TXA2 is produced primarily by platelets, but there is evidence of the synthesis of the vasoconstrictor metabolite by the endothelium (Sellers \& Stallone 2008). $\mathrm{E}_{2}$ did not change TXA2 production in our experiments. The literature indirectly suggests that estrogen would have a beneficial effect by decreasing the production of thrombogenic compounds. For instance, there is a decrease in the formation of TXA2 in men after the use of high-dosage i.m. estrogen therapy (Henriksson et al. 1996). Moreover, the ratio of in vivo PGI2 to TXA2 formation increased twofold during estrogen replacement therapy (Mueck et al. 2001). Nevertheless, it has also been documented that estrogen increases platelet activation with the liberation of TXA2 in women treated with hormone replacement therapy (Oliveira et al. 2005), and that estrogen enhances the constrictor prostanoid function in female rat aorta (Li et al. 2008).

The relative role of both subtypes of ERs in prostanoid production has been scarcely documented, with only the involvement of ER $\beta$ in the $\mathrm{E}_{2}$-increased production of PGI2 in fetal ovine pulmonary artery endothelium being described so far (Sherman et al. 2002).

Despite cPLA2's important role as the hormonesensitive substance in PGI2 production in response to various agonists such as angiotensin II or bradykinin, and its high expression levels in HUVECs and umbilical smooth muscle cells (Ost et al. 1998), it does not appear to be regulated by $\mathrm{E}_{2}$. Our results are in agreement with previous studies showing no effect in either $\mathrm{E}_{2}$-treated cerebral arteries (Ospina et al. 2002) or in human myometrial cells prepared from second trimester pregnant women after stimulation with $\mathrm{E}_{2}$ (Korita et al. 2004).

The present study found increased levels of COX-1 mRNA and protein expression in $\mathrm{E}_{2}$-treated HUVECs, with a concomitant elevation of PGI2 synthesis, through $\mathrm{ER} \alpha$ activation. That notwithstanding, COX-2 mRNA

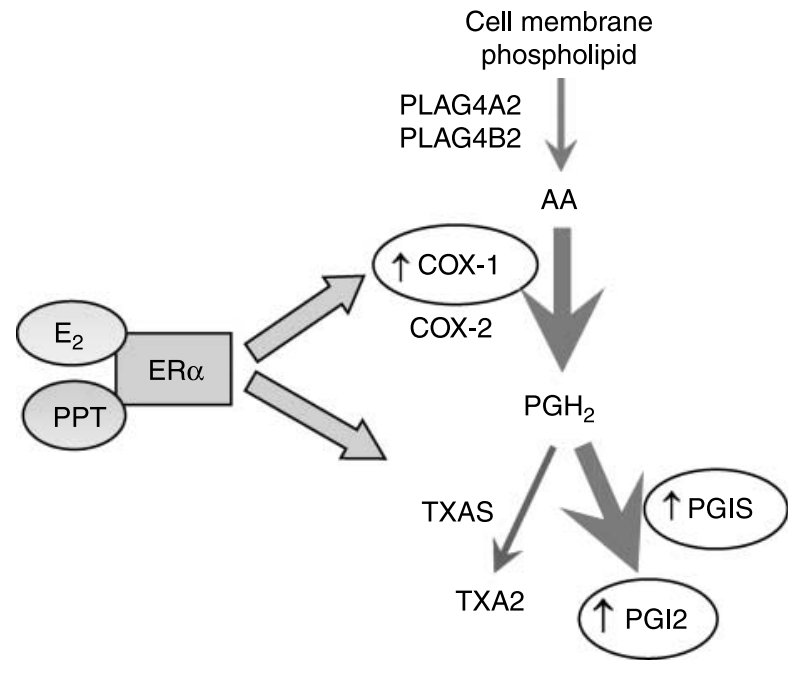

Figure 9 Estradiol-induced modifications on prostanoid pathway through $E R \alpha$. Estradiol $\left(E_{2}\right)$ or the $E R \alpha$ agonist (PPT) acting on $\mathrm{ER} \alpha$ increased cyclooxygenase-1 (COX-1) and prostacyclin synthase (PGIS) expression and resulted in an increased prostacyclin (PGI2) production. Phospholipase A2 subunit (PLAG4A2 and PLAG4B2), cyclooxygenase-2 (COX-2), and thromboxane synthase (TXAS) expressions, along with thromboxane A2 production (TXA2), remained unchanged after exposure to $E_{2}$. 
and protein expression did not appear to be modified in HUVECs treated with $\mathrm{E}_{2}$. Subsequently, controversy exists over the effects of $\mathrm{E}_{2}$ on COX expression. Even though $\mathrm{E}_{2}$ has been reported to up-regulate COX-1 expression in ovine fetal pulmonary artery endothelial cells (Jun et al. 1998), it has also been reported to selectively increase COX-2 expression in HUVECs (Akarasereenont et al. 2000), and not to modify COX-1 or COX-2 expression in bovine coronary endothelial cells (Stewart et al. 1999). Moreover, $\mathrm{E}_{2}$ has been reported to increase COX-1 expression through $\mathrm{ER} \alpha$ in ovine endothelial cells transfected with the human COX-1 promoter (Gibson et al. 2005). Our data describe for the first time an ER $\alpha$-dependent increase of COX-1 expression in human cells, similar to that reported for other vascular enzymes responsible for vasodilator production, such as endothelial nitric oxide synthase (Traupe et al. 2007).

To complete the prostanoid pathway, PGIS mRNA levels and protein content were increased in HUVECs exposed to $\mathrm{E}_{2}$ through $\mathrm{ER} \alpha$, whereas TXAS mRNA expression remained unmodified. An $\mathrm{E}_{2}$-increased PGIS and COX-1 protein expression has already been described in rat cerebral artery (Ospina et al. 2002), and $\mathrm{E}_{2}$-up-regulated COX-2 and TXAS expression has been described in rat aorta ( $\mathrm{Li}$ et al. 2008). Although it has been proposed that PGIS preferentially couples with COX-2 for the production of PGI2 (Ueno et al. 2001) in cultured cells, our data have indicated that PGIS would be up-regulated mainly with COX-1 in HUVECs exposed to $\mathrm{E}_{2}$ in accordance with a published outcome for sheep (Rupnow et al. 2002). TXAS, in turn, can be up-regulated along with COX-2 (Doroudi et al. 2000), and COX-2 can be up-regulated by TXA2 (Caughey et al. 2001), suggesting a closer relationship between COX-2 and TXAS. In our results, both COX-2 and TXAS remained unaltered after exposure to $\mathrm{E}_{2}$.

Molecular, cellular, and animal studies have convincingly demonstrated that $\mathrm{E}_{2}$ has favorable effects on vascular cells, with many of them being achieved through ER-dependent signaling responses. Both ER $\alpha$ and ER $\beta$ may have distinct roles in the vascular wall (Meyer \& Barton 2009). Most of the beneficial vasculoprotective actions of $\mathrm{E}_{2}$ are mediated by $\mathrm{ER} \alpha$. Our results add new information that supports a role for $\mathrm{ER} \alpha$ in $\mathrm{E}_{2}$-mediated vasodilatory effects. Therefore, $\mathrm{E}_{2}$ stimulates not only nitric oxide production but also PGI2 production through $\mathrm{ER} \alpha$, via both genomic and non-genomic pathways (Chen et al. 1999, Traupe et al. 2007). In addition, $\mathrm{ER} \alpha$ agonists have been shown to improve endothelial dysfunction in rat blood vessels (Widder et al. 2003). Moreover, ER $\alpha$ mediates atheroprotective effects (Hodgin et al. 2001). Finally, impaired vascular function and premature coronary artery disease were noted in a man with a disruptive mutation in the ERo gene (Sudhir et al. 1997).
In conclusion, the present study demonstrates that $\mathrm{E}_{2}$ increases vasodilatory response mediated by $\mathrm{ER} \alpha$ in HUVECs, since $\mathrm{E}_{2}$ selectively up-regulates the protein expression of COX-1 and PGIS enzymes, which would turn the prostanoid balance toward PGI2 production, without affecting TXAS expression or TXA production (Fig. 9).

\section{Declaration of interest}

The authors declare that there is no conflict of interest that could be perceived as prejudicing the impartiality of the research reported.

\section{Funding}

This work was supported by the Spanish Ministerio de Ciencia e Innovación, Instituto de Salud Carlos III (grants FIS 06/0589 and Red HERACLES RD06/0009/0005), the Consellería de Sanidad, Generalitat Valenciana (AP 121/2008 and GE-007/09), and the Consellería de Educación, Generalitat Valenciana (grant GVPRE/2008/276). $\mathrm{P}$ J Oviedo holds a post-doctorate position, and A Sobrino is a fellowship recipient from the FPI program (BFPI 06/145), both from the Consellería de Educación, Generalitat Valenciana, Spain.

\section{Acknowledgements}

The authors are indebted to Mrs Elvira Calap and Mrs Rosa Aliaga for their excellent technical assistance.

\section{References}

Akarasereenont P, Techatraisak K, Thaworn A \& Chotewuttakorn S 2000 The induction of cyclooxygenase-2 by 17 beta-estradiol in endothelial cells is mediated through protein kinase C. Inflammation Research 49 460-465.

Arnal JF, Gourdy P, Elhage R, Garmy-Susini B, Delmas E, Brouchet L, Castano C, Barreira Y, Couloumiers JC, Prats H et al. 2004 Estrogens and atherosclerosis. European Journal of Endocrinology 150 113-117.

Barrett-Connor E \& Grady D 1998 Hormone replacement therapy, heart disease, and other considerations. Annual Review of Public Health 19 55-72.

Billon-Galés A, Fontaine C, Filipe C, Douin-Echinard V, Fouque MJ, Flouriot G, Gourdy P, Lenfant F, Laurell H, Krust A et al. 2009 The transactivating function 1 of estrogen receptor $\alpha$ is dispensable for the vasculoprotective actions of $17 \beta$-estradiol. PNAS 106 2053-2058.

Bunting S, Moncada S \& Vane JR 1983 The prostacyclin-thromboxane A2 balance: pathophysiological and therapeutic implications. British Medical Bulletin 39 271-276.

Cano A \& Hermenegildo C 2000 Modulation of the oestrogen receptor: a process with distinct susceptible steps. Human Reproduction Update 6 207-211.

Cano A, Hermenegildo C, Oviedo P \& Tarin JJ 2007 The risk for cardiovascular disease in women: from estrogens to selective estrogen receptor modulators. Frontiers in Bioscience 12 49-68. 
Caughey GE, Cleland LG, Gamble JR \& James MJ 2001 Up-regulation of endothelial cyclooxygenase-2 and prostanoid synthesis by platelets. Role of thromboxane A2. Journal of Biological Chemistry 276 37839-37845.

Chen Z, Yuhanna IS, Galcheva-Gargova Z, Karas RH, Mendelsohn ME \& Shaul PW 1999 Estrogen receptor alpha mediates the nongenomic activation of endothelial nitric oxide synthase by estrogen. Journal of Clinical Investigation 103 401-406.

Doroudi R, Gan LM, Selin Sjogren L \& Jern S 2000 Effects of shear stress on eicosanoid gene expression and metabolite production in vascular endothelium as studied in a novel biomechanical perfusion model. Biochemical and Biophysical Research Communications 269 257-264.

Gibson LL, Hahner L, Osborne-Lawrence S, German Z, Wu KK, Chambliss KL \& Shaul PW 2005 Molecular basis of estrogeninduced cyclooxygenase type 1 upregulation in endothelial cells. Circulation Research 96 518-525.

Grady D, Herrington D, Bittner V, Blumenthal R, Davidson M, Hlatky M, Hsia J, Hulley S, Herd A, Khan S et al. 2002 Cardiovascular disease outcomes during 6.8 years of hormone therapy: Heart and Estrogen/Progestin Replacement Study follow-up (HERS II). Journal of the American Medical Association 288 $49-57$.

Harris HA 2007 Estrogen receptor- $\beta$ : recent lessons from in vivo studies. Molecular Endocrinology 21 1-13.

Haynes MP, Li L, Sinha D, Russell KS, Hisamoto K, Baron R, Collinge M, Sessa WC \& Bender JR 2003 Src kinase mediates phosphatidylinositol 3-kinase/Akt-dependent rapid endothelial nitric-oxide synthase activation by estrogen. Journal of Biological Chemistry 278 2118-2123.

Henriksson P, Stege R \& Green K 1996 Profound decrease of in vivo formation of thromboxane during oestrogen therapy. European Journal of Clinical Investigation 26 1186-1188.

Hermenegildo C, Garcia-Martinez MC, Tarin JJ \& Cano A 2002 Estradiol reduces F2alpha -isoprostane production in cultured human endothelial cells. American Journal of Physiology. Heart and Circulatory Physiology 283 H2644-H2649.

Hermenegildo C, Oviedo PJ \& Cano A 2006 Cyclooxygenases regulation by estradiol on endothelium. Current Pharmaceutical Design 12 205-215.

Hodgin JB, Krege JH, Reddick RL, Korach KS, Smithies O \& Maeda N 2001 Estrogen receptor $\alpha$ is a major mediator of $17 \beta$-estradiol's atheroprotective effects on lesion size in Apoe ${ }^{-/-}$mice. Journal of Clinical Investigation 107 333-340.

Hulley S, Grady D, Bush T, Furberg C, Herrington D, Riggs B \& Vittinghoff E 1998 Randomized trial of estrogen plus progestin for secondary prevention of coronary heart disease in postmenopausal women. Heart and Estrogen/Progestin Replacement Study (HERS) Research Group. Journal of the American Medical Association 280 605-613.

Jun SS, Chen Z, Pace MC \& Shaul PW 1998 Estrogen upregulates cyclooxygenase-1 gene expression in ovine fetal pulmonary artery endothelium. Journal of Clinical Investigation 102 176-183.

Kim KH \& Bender JR 2009 Membrane-initiated actions of estrogen on the endothelium. Molecular and Cellular Endocrinology 308 3-8.

Korita D, Itoh H, Sagawa N, Yura S, Yoshida M, Kakui K, Takemura M \& Fujii S 2004 17[beta]-estradiol up-regulates prostacyclin production in cultured human uterine myometrial cells via augmentation of both cyclooxygenase-1 and prostacyclin synthase expression. Journal of the Society for Gynecologic Investigation 11 457-464.

Krom YD, Pires NMM, Jukema JW, de Vries MR, Frants RR, Havekes LM, van Dijk KW \& Quax PHA 2007 Inhibition of neointima formation by local delivery of estrogen receptor alpha and beta specific agonists. Cardiovascular Research $\mathbf{7 3}$ 217-226.
Li M, Kuo L \& Stallone JN 2008 Estrogen potentiates constrictor prostanoid function in female rat aorta by upregulation of cyclooxygenase-2 and thromboxane pathway expression. American Journal of Physiology. Heart and Circulatory Physiology 294 H2444-H2455.

Lowry OH, Rosebrough NJ, Farr AL \& Randall RJ 1951 Protein measurement with the Folin phenol reagent. Journal of Biological Chemistry 196 265-275.

Mendelsohn ME \& Karas RH 2005 Molecular and cellular basis of cardiovascular gender differences. Science $\mathbf{3 0 8}$ 1583-1587.

Meyer MR \& Barton M 2009 ER \{alpha\}, ER $\{$ beta\}, and gpER: novel aspects of oestrogen receptor signalling in atherosclerosis. Cardiovascular Research 83 605-610.

Mikkola T, Turunen P, Avela K, Orpana A, Viinikka L \& Ylikorkala O 199517 beta-estradiol stimulates prostacyclin, but not endothelin-1, production in human vascular endothelial cells. Journal of Clinical Endocrinology and Metabolism 80 1832-1836.

Monsalve E, Oviedo PJ, Garcia-Perez MA, Tarin JJ, Cano A \& Hermenegildo C 2007 Estradiol counteracts oxidized LDL-induced asymmetric dimethylarginine production by cultured human endothelial cells. Cardiovascular Research 73 $66-72$.

Mueck AO, Seeger H, Ludtke R, Graser T \& Wallwiener D 2001 Effect on biochemical vasoactive markers during postmenopausal hormone replacement therapy: estradiol versus estradiol/ dienogest. Maturitas 38 305-313.

Oliveira RL, Aldrighi JM, Gebara OE, Rocha TRF, D'Amico E, Rosano GMC \& Ramires JA 2005 Postmenopausal hormone replacement therapy increases plasmatic thromboxane [beta]2. International Journal of Cardiology 99 449-454.

Ospina JA, Krause DN \& Duckles SP 2002 17beta-estradiol increases rat cerebrovascular prostacyclin synthesis by elevating cyclooxygenase-1 and prostacyclin synthase. Stroke 33 600-605.

Ost M, Uhl E, Carlsson M, Gidlof A, Soderkvist P \& Sirsjo A 1998 Expression of mRNA for phospholipase A2, cyclooxygenases, and lipoxygenases in cultured human umbilical vascular endothelial and smooth muscle cells and in biopsies from umbilical arteries and veins. Journal of Vascular Research 35 150-155.

Oviedo PJ, Hermenegildo C \& Cano A 2004 Raloxifene increases the capacity of serum to promote prostacyclin release in human endothelial cells: implication of COX-1 and COX-2. Menopause 11 430-437.

Oviedo PJ, Hermenegildo C, Tarin JJ \& Cano A 2007 Raloxifene increases proliferation of human endothelial cells in association with increased gene expression of cyclins A and B1. Fertility and Sterility 88 326-332.

Pfaffl MW, Horgan GW \& Dempfle L 2002 Relative expression software tool $(\operatorname{REST}(\mathrm{C}))$ for group-wise comparison and statistical analysis of relative expression results in real-time PCR. Nucleic Acids Research 30 e36.

Rupnow HL, Phernetton TM, Modrick ML, Wiltbank MC, Bird IM \& Magness RR 2002 Endothelial vasodilator production by uterine and systemic arteries. VIII. Estrogen and progesterone effects on cPLA2, COX-1, and PGIS protein expression. Biology of Reproduction 66 468-474.

Sellers MM \& Stallone JN 2008 Sympathy for the devil: the role of thromboxane in the regulation of vascular tone and blood pressure. American Journal of Physiology. Heart and Circulatory Physiology 294 H1978-H1986.

Sherman TS, Chambliss KL, Gibson LL, Pace MC, Mendelsohn ME, Pfister SL \& Shaul PW 2002 Estrogen acutely activates prostacyclin synthesis in ovine fetal pulmonary artery endothelium. American Journal of Respiratory Cell and Molecular Biology 26 610-616.

Stewart KG, Zhang Y \& Davidge ST 1999 Estrogen decreases prostaglandin $\mathrm{H}$ synthase products from endothelial cells. Journal of the Society for Gynecologic Investigation 6 322-327. 
Sudhir K, Chou TM, Messina LM, Hutchison SJ, Korach KS, Chatterjee K \& Rubanyi GM 1997 Endothelial dysfunction in a man with disruptive mutation in oestrogen-receptor gene. Lancet 349 1146-1147.

Toth B, Scholz C, Saadat G, Geller A, Schulze S, Mylonas I, Friese K \& Jeschke U 2008 Estrogen receptor modulators and estrogen receptor beta immunolabelling in human umbilical vein endothelial cells. Acta Histochemica 111 508-519.

Traupe T, Stettler CD, Li H, Haas E, Bhattacharya I, Minotti R \& Barton M 2007 Distinct roles of estrogen receptors $\alpha$ and $\beta$ mediating acute vasodilation of epicardial coronary arteries. Hypertension 49 1364-1370.

Turgeon JL, Carr MC, Maki PM, Mendelsohn ME \& Wise PM 2006 Complex actions of sex steroids in adipose tissue, the cardiovascular system, and brain: insights from basic science and clinical studies. Endocrine Reviews 27 575-605.
Ueno N, Murakami M, Tanioka T, Fujimori K, Tanabe T, Urade Y \& Kudo I 2001 Coupling between cyclooxygenase, terminal prostanoid synthase, and phospholipase A2. Journal of Biological Chemistry 276 34918-34927.

Wagner AH, Schroeter MR \& Hecker M 2001 17beta-estradiol inhibition of NADPH oxidase expression in human endothelial cells. FASEB Journal 15 2121-2130.

Widder J, Pelzer T, von Poser-Klein C, Hu K, Jazbutyte V, Fritzemeier KH, Hegele-Hartung C, Neyses L \& Bauersachs J 2003 Improvement of endothelial dysfunction by selective estrogen receptor- $\alpha$ stimulation in ovariectomized SHR. Hypertension 42 991-996.

Received in final form 7 December 2009

Accepted 28 January 2010

Made available online as an Accepted Preprint

28 January 2010 